\title{
The Correlation of Open Learning, Collaboration, Learning Tools, and Creative Problem Solving by Graduate Students in Thailand
}

\author{
https://doi.org/10.3991/ijet.v13i09.7835 \\ Narin Nonthamand( $\left.{ }^{\bowtie}\right)$, Jaitip Na Songkhla \\ Chulalongkorn University, Bangkok, Thailand \\ Narin.Nestudent.chula.ac.th
}

\begin{abstract}
Objectives of this research study were to investigate the correlation and forecast the independent variables of the correlation of opinions regarding open learning, collaboration, creative problem solving and usage level of teaching and learning media for graduate students in Thailand. The open learning focused on giving students access to the content from the university for free, encouragement to share their experiences and comment with students in higher education institutions and prospective learners who were interested in the courses via learning tools to communicate, work and learn together. It is also a guideline to develop an instructional design open learning model to enhance creative problem solving ability of higher education students. It was a quantitative research study which used a questionnaire to collect data. The question items in the instrument were check listed and a rating scale was established which had been approved for validity by 7 experts. The samples consisted of 419 higher education students from 16 universities using correlation analysis and multiple regression analysis. Findings revealed as follows; 1. determined: Open learning was positively related to team working and willingness to work with others, group discussion behaviors, usage of teaching and learning media, and creative problem solving abilities. The highest results included the correlation of group discussion and creative problem solving abilities at $609^{* *}$. 2. included: Applied statistics methods including coefficient correlation analysis and multiple regression analysis were used to analyze open learning, group behavior, usage of teaching and learning media, creative problem solving abilities and resulted with the forecast equation showing creative problem solving abilities $=.524$, open learning $=+.111$, team working $=+.317$, duty to work with others $=+.099$, group discussion behavior $=*+.371$, usage level of teaching and learning media $=+.087$
\end{abstract}

Keywords—open learning, team working, learning tools, creative problem solving.

\section{Introduction}

A creative problem solving ability is an important qualification that learners should possess when they graduate from an institution of Higher Education. Students are 
expected to be able to solve complicated problems systematically by applying their knowledge and using proper and various solutions. It is also the required qualification of bachelor students based on Thailand National Policy Framework (B.E. 2554-2563 (ICT 2020) and The 12 National Main Values by National Peace and order Maintaining Council. It is also an important qualification for 21 st century skills which requires that learners have creative thinking skills and can develop innovative solutions with deliberation, and possess the ability to solve problem when they graduate and are able to apply their creative thinking abilities to solve different complex problems [1].

Effective problem solving refers to the concept of solving a problem, finding solutions, generating different and better feasible solutions that are proper and bring about increased understanding to resolve the problem [2]. Students must understand the problem, solution and planning accordingly for further application and effectiveness [3][4].

Creative problem solving depends on various ideas to solve a problem and generate a creative solution. One of the best methods which learners can apply to improve their creative problem solving thinking is to learn different group techniques in terms of the process to utilize learners' abilities [5]. In the group process, learners exchange their experiences, knowledge, opinions and different data. At the same time, they learn to listen to others' opinions which will make the group or team work effectively and achieve its goal. In order to have an effective collaboration, it depends on the characteristics of individual group members and the quality of working with others in order to generate different activities. In the group, teachers or instructors must develop activities designed to help the group achieve the learning objectives. Important things to help make the group process more effective include: willingness to work with others, individual commitment to work with others, and group discussion behavior of the learners both inside and outside of the curriculum [6].

To help learners develop abilities to solve problems creatively requires different concepts based on different experiences. Especially for the present, technology is applied to support education in terms of different tools that facilitate learners to access the knowledge faster and conveniently anywhere and anytime [7][8]. In addition, learners can also learn on computer and internet networks, so different teaching or social media online are important for learners to acquire these basic skills. Since tools or media can support co-working for improved communication and activities with open learning by using time integrating or non-time integrating tools, cloud storage and social network [9].

In addition, different online learning courses are highly popular nowadays and can access many learners at the same time on different websites. In contrast, instructors in the open university can provide chances for interested learners who do not officially enroll in a course to take the course or related, subject matter with co-learning activities, teaching media and technology without fees based on open learning by focusing on the benefit of learning, working with others and knowledge application [10]. Learners are able to see the whole picture, exchange their experience and knowledge, and collaborate with others in a learning experience. Learners registered in the course and non-fee based can learn the subject matter directly, practice with experience personnel or specialists, and develop team work skills, change their behaviors, learn and 
practice working as a team, and discuss or express their ideas through online teaching and learning media [11].

This study's researcher analyzed the correlation of different variables as they relate to creative problem solving abilities. He also determined guidelines for the development of creative problem solving for graduate students in Thailand and identified the advantage for open learning design by the instructors.

\section{Population and sample group in this research}

The sample included 416 graduate students studying in universities in Thailand belonging to the Office of the Higher Education Commission. These participants were recruited with a stratified random sampling method and grouped as four groups based on the type of the institute. Types included public universities under the supervision of the government, private universities and a Rajabhat university. Samples were recruited from the faculty of humanity, social science and science programs for bachelor, master and doctor degrees.

\section{Applied tools to collect data and data collection}

The instrument used was a questionnaire asking about circumstance and need for open learning for learners in universities in Thailand. The questions were developed based on concept and elements obtained from a literature review, Specialist in Education technology and communication, measurement and evaluation 7 experts to check the quality of the content validity with 29 items, Index of Item-Objective Congruence (IOC) [12] which was used to find the content validity. The IOC was used to evaluate the items of the questionnaire based on the score range from -1 to +1 . In this research the IOC $=0.99$ with was in the range of $0.71-1.00$, the assessment was suitable and applicable afterwards try out with the 30 students in the non sample group, Cronbach's alpha coefficient was 0.881 , which was in high reliability [13].

The concepts of open learning, group processing concept, and creative problem solving. Questions in the questionnaire included a checklist and rating scale items plus open ended questions. The researcher asked sample groups to answer the questionnaire online, then collected all questionnaires, and later analyzed the results. Data analysis included correlation analysis and multiple regression analysis for opinions gathered regarding open learning, working in a team, creative problem solving abilities, and usage levels of teaching and learning media of graduate students.

\section{$4 \quad$ Research finding}

Research findings showed that the concept of open learning, working collaboratively, commitment to working with others, group discussion behavior, the usage of teaching and learning media and creative problem solving abilities were related. Duty to work with others related to Group discussion behavior at $.654^{* *}$ and related the 
most and positively with guidelines for interpreting the strength of the correlation as described in the following table.

Table 1. guidelines for interpreting the strength of the correlation

\begin{tabular}{|c|c|c|}
\hline \multicolumn{2}{|c|}{ Size of Correlation } & \multirow{2}{*}{ General coefficient interpretation } \\
\hline Type 1 [14] & Type 2 [15] & Weak to no relationship \\
\hline $0.0-0.2$ & $0.0-0.3$ & Weak relationship \\
\hline $0.2-0.4$ & $0.3-0.5$ & Moderate relationship \\
\hline $0.4-0.6$ & $0.5-0.7$ & Strong relationship \\
\hline $0.6-0.8$ & $0.7-0.9$ & Very strong relationship \\
\hline $0.8-1.0$ & $0.9-1.0$ & \\
\hline
\end{tabular}

Table 2. coefficient correlation of open learning, working with others, duty to work with others, group discussion behavior, creative problem solving abilities and the usage of teaching and learning media

\begin{tabular}{|c|c|c|c|c|c|c|}
\hline \multirow[b]{2}{*}{ Variables to study } & \multicolumn{6}{|c|}{ Correlation } \\
\hline & $\begin{array}{c}\text { Open } \\
\text { Learning }\end{array}$ & $\begin{array}{c}\text { Working } \\
\text { with others }\end{array}$ & $\begin{array}{c}\text { Duty to } \\
\text { work with } \\
\text { others }\end{array}$ & $\begin{array}{c}\text { Group } \\
\text { discussion } \\
\text { behavior }\end{array}$ & $\begin{array}{c}\text { Creative } \\
\text { problem } \\
\text { solving } \\
\text { abilities }\end{array}$ & $\begin{array}{l}\text { Usage of } \\
\text { learning } \\
\text { and teach- } \\
\text { ing media }\end{array}$ \\
\hline Open learning & 1 & & & & & \\
\hline Working with others & $.385 * *$ & 1 & & & & \\
\hline Duty to work with others & $.210 * *$ & $.528 * *$ & 1 & & & \\
\hline Group discussion behavior & $.305 * *$ & $.561 * *$ & $.654 * *$ & 1 & & \\
\hline $\begin{array}{l}\text { Creative problem solving } \\
\text { abilities }\end{array}$ & $.362 * *$ & $.561 * *$ & $.504 * *$ & $.609 * *$ & 1 & \\
\hline $\begin{array}{l}\text { Usage of teaching and } \\
\text { learning media }\end{array}$ & $.176^{* *}$ & $.250 * *$ & $.312 * *$ & $.293 * *$ & $.334 * *$ & 1 \\
\hline
\end{tabular}

**.Correlation is significant at the 0.01 level (2-tailed).

Table 2 shows that The Pearson's $r$ for the correlation between Duty to work with others and Group discussion behavior have the most relationship $=.654 * *$ second one of the correlation between Group discussion behavior and Creative problem solving abilities $=.609^{* *}$ and the correlation between Working with others and Duty to work with others $=.528^{* *}$ respectively. This means that there is a strong relationship between two variables. This means that changes in one variable are strongly correlated with changes in the second variable.

Next, the researcher applied multiple regression analysis regarding opinions towards open learning, working with others, duty to work with others, group discussion behavior, usage level of teaching and learning media and creative problem solving abilities and got the following result. (Refer to Table 3) 
Table 3. Multiple regression analysis of opinions towards open learning, working with others, duty to work with others, group discussion behavior, usage level of teaching and learning media and creative problem solving abilities.

\begin{tabular}{|c|c|c|c|c|c|c|}
\hline \multicolumn{7}{|c|}{ Coefficients $^{a}$} \\
\hline & \multirow{2}{*}{ Model } & \multicolumn{2}{|c|}{$\begin{array}{c}\text { Unstandardized } \\
\text { Coefficients }\end{array}$} & \multirow{2}{*}{\begin{tabular}{|c|}
$\begin{array}{c}\text { Standardized } \\
\text { Coefficients }\end{array}$ \\
Beta \\
\end{tabular}} & \multirow[t]{2}{*}{$t$} & \multirow{2}{*}{ Sig. } \\
\hline & & $B$ & Std. Error & & & \\
\hline \multirow{6}{*}{1} & (Constant) & .524 & .187 & & 2.796 & .005 \\
\hline & 1. Group discussion behavior & .371 & .059 & .346 & 6.323 & .000 \\
\hline & 2. Working with others & .317 & .064 & .247 & 4.988 & .000 \\
\hline & 3. Usage level of teaching and learning media & .087 & .029 & .119 & 2.968 & .003 \\
\hline & 4. Open learning & .111 & .039 & .117 & 2.838 & .005 \\
\hline & 5. Duty to work with others & .099 & .063 & .083 & 1.564 & .119 \\
\hline
\end{tabular}

Dependent Variable: Creative Problem Solving

Predictors: (Constant), Group discussion behavior Working with others, Usage level of teaching and learning media, Open learning, Duty to work with others

$*_{\mathrm{p}}<.05$, significant at the .05 level

Table 3 showed that dependent variables influenced creative problem solving abilities with 4 variables predicting including group discussion behavior with the prediction coefficient $\left(\mathrm{R}^{2}\right)=.346$ that show group discussion behavior variables supporting creative problem solving abilities 34.60 percentage and the variable predicting equation No. 2, working with others with the prediction coefficient $\left(\mathrm{R}^{2}\right)=.247$ that show working with others variables supporting creative problem solving abilities 24.70 percentage and the variable predicting equation No. 3, usage level of teaching and learning with the prediction coefficient $\left(\mathrm{R}^{2}\right)=.119$ that show usage level of teaching and learning variables supporting creative problem solving abilities 11.90 percentage and the variable predicting equation No. 4, open learning with the prediction coefficient $\left(\mathrm{R}^{2}\right)=.117$ that show open learning variables supporting creative problem solving abilities 11.70 percentage. It was concluded that dependent variables influencing creative problem solving abilities with the statistics significant at .05 , the prediction coefficient $\left(\mathrm{R}^{2}\right)=.476$ that showed group discussion behavior and working with others, usage level of teaching and learning media and open learning which could explain variance of creative problem solving abilities at 47.60 percentage, four variables cooperated to support creative problem solving abilities.

The obtained equation for creative problem solving abilities $=.524+.111$, open learning +.317 , working with others +.099 , duty to work with others $*+.371$, group discussion behavior +087 , and usage level of teaching and learning media.

The analysis revealed the correlation and dependent variables influencing creative problem solving abilities excluding duty to work with other. The researcher, therefore, proposed details of dependent variables influencing creative problem solving abilities as open learning, working with others, group discussion behavior, usage level of teaching and learning media and data collection from 416 samples, and we had found different dependent variables could explain the variable as below. 
The samples reported first three percentile ranked benefits of open learning as learning something new (Mean=3.97), the chance to make new friends, and learning about other learners' habits (Mean=3.92), and the chance to practice using learning media (Mean=3.78). The benefits of working with others included a way to exchange ideas and knowledge (Mean=4.10), receiving different knowledge from different sources (Mean=4.07), the chances to practice thinking and studying from different sources (Mean=3.94). The benefits of practical knowledge application with open learning included learning and experiencing working from other learners (Mean=3.96), having different points of view towards working and knowledge application (Mean =3.91), and the ability to apply one's knowledge with the work (Mean=3.87).

The benefits of working with others included listening to others' ideas $($ Mean=3.41), the access to source information for work (Mean=3.21), and the ability to include colleagues' ideas (Mean =3.09).

The benefits of group discussion behavior included listening to group members' ideas (Mean=3.32); collecting ideas from group members (Mean =3.13); and the motivation, support, and encouragement received from group members (Mean =3.09).

The usage level of teaching and learning media included time integrating tools, namely in the Discussion room (Mean=3.18), Live video (Mean=2.11), Teleconferencing (Mean=1.56), non-time integrating tools including email (Mean=3.21), group division (Mean $=2.88)$, calendar use (Mean=2.88), cloud storage namely Google drive $($ Mean $=3.21)$, Dropbox $($ Mean $=2.60)$, One drive $($ Mean $=2.10)$, and social media including Facebook: (Mean =4.65), Line (Mean =4.46) and Instagram (Mean =3.31).

Further, regarding the three first ranked variables, the researcher had analyzed all questions about each variable as coefficient correlations using multiple regression analysis with stepwise selection to study variables in each variable group and concluded in Table 4.

Table 4 shows that dependent variables influenced creative problem solving abilities with 11 variables predicting No. 1, Being assistant of colleague to complete the job with the prediction coefficient $\left(\mathrm{R}^{2}\right)=.215$ that show Being assistant of colleague to complete the job variable supporting creative problem solving abilities 21.50 percentage and the variable predicting equation No. 2 , Collect different ideas from group members with the prediction coefficient $\left(\mathrm{R}^{2}\right)=.193$ that show Collect different ideas from group members variable supporting creative problem solving abilities 19.30 percentage and the variable predicting equation No. 3 , Take care of the venue to share ideas with the prediction coefficient $\left(\mathrm{R}^{2}\right)=.135$ that show Take care of the venue to share ideas variable supporting creative problem solving abilities 13.50 percentage respectively. All variables explain the variance of ability to solve problems creatively with the statistics significant at .05 , the prediction coefficient $\left(\mathrm{R}^{2}\right)=.504$ that showed Being assistant of colleague to complete the job, Collect different ideas from group members, Take care of the venue to share ideas, Provide lecture and allow members to express their ideas, Record things and report the progress of idea expression, Encourage, support and motivate group members, Express ideas with voting, Suggest some solution to solve problem in the group, Bulletin board, Make more friends and learn their habit, Have various view of point and able to apply the knowledge which 
could explain variance of creative problem solving abilities at 50.40 percentage, eleven variables of four variables group cooperated to support creative problem solving abilities.

Table 4. Multiple regression analysis all questions of opinions towards duty to work with others, group discussion behavior, usage of teaching and learning media, open learning and creative problem solving abilities.

\begin{tabular}{|c|c|c|c|c|c|c|}
\hline \multicolumn{7}{|c|}{ Coefficients $^{\mathrm{a}}$} \\
\hline \multirow{2}{*}{\multicolumn{2}{|c|}{ Model }} & \multicolumn{2}{|c|}{$\begin{array}{l}\text { Unstandard- } \\
\text { ized Coeffi- } \\
\text { cients }\end{array}$} & \multirow{2}{*}{$\begin{array}{c}\begin{array}{c}\text { Standard- } \\
\text { ized Coeffi- } \\
\text { cients }\end{array} \\
\text { Beta }\end{array}$} & \multirow[t]{2}{*}{$t$} & \multirow[t]{2}{*}{ Sig. } \\
\hline & & $B$ & $\begin{array}{l}\text { Std. } \\
\text { Error }\end{array}$ & & & \\
\hline \multicolumn{2}{|l|}{ (Constant) } & .798 & .158 & & 5.045 & .000 \\
\hline $\begin{array}{l}\text { Duty to work } \\
\text { with others }\end{array}$ & $\begin{array}{l}\text { Being assistant of colleague to complete } \\
\text { the job. }\end{array}$ & .194 & .038 & .215 & 5.153 & .000 \\
\hline \multirow{7}{*}{$\begin{array}{l}\text { Group discus- } \\
\text { sion behavior }\end{array}$} & $\begin{array}{l}\text { Collect different ideas from group mem- } \\
\text { bers. }\end{array}$ & .141 & .031 & .193 & 4.499 & .000 \\
\hline & Take care of the venue to share ideas. & .095 & .034 & .135 & 2.827 & .005 \\
\hline & $\begin{array}{l}\text { Provide lecture and allow members to } \\
\text { express their ideas. }\end{array}$ & .139 & .040 & .129 & 3.448 & .001 \\
\hline & $\begin{array}{l}\text { Record things and report the progress of } \\
\text { idea expression }\end{array}$ & .085 & .031 & .123 & 2.698 & .007 \\
\hline & $\begin{array}{l}\text { Encourage, support and motivate group } \\
\text { members. }\end{array}$ & .068 & .034 & .090 & 1.980 & .048 \\
\hline & Express ideas with voting. & .082 & .039 & .080 & 2.128 & .034 \\
\hline & $\begin{array}{l}\text { Suggest some solution to solve problem in } \\
\text { the group. }\end{array}$ & .057 & .027 & .088 & 2.117 & .035 \\
\hline $\begin{array}{l}\text { Usage of } \\
\text { teaching and } \\
\text { learning } \\
\text { media }\end{array}$ & Bulletin board & .050 & .016 & .126 & 3.218 & .001 \\
\hline \multirow[b]{2}{*}{ Open learning } & Make more friends and learn their habit & .081 & .028 & .118 & 2.848 & .005 \\
\hline & $\begin{array}{l}\text { Have various view of point and able to } \\
\text { apply the knowledge }\end{array}$ & .071 & .026 & .109 & 2.690 & .007 \\
\hline
\end{tabular}

Dependent Variable: Creative Problem Solving

Predictors: (Constant), Duty to work with others, Group discussion behavior,Usage of teaching and learning media,Open learning

$* \mathrm{p}<.05$, significant at the .05 level

\section{Summary and conclusion}

Findings showed positive opinions towards open learning related to working with others, duty to working with others, group discussion behaviors, usage of teaching and learning media, and creative problem solving abilities. The most positive correla- 
tion $\left(609^{* *}\right)$ was related to group discussion behaviors and the ability to solve problems creatively.

Dependent variables influencing creative problem solving abilities were group discussion behaviors and working with others. Usage levels of teaching and learning media and open learning could explain the variance of creative problem solving abilities at 47.60 percentage.

Entering all variables in the study showed that several factors influenced and created variance towards creative problem solving abilities in correlation coefficient with multiple regression analysis using stepwise selection, as explained below.

Based on the obtained findings, the researcher designed a teaching program to develop creative problem solving abilities using different related variables and variances that influenced the results. It was found that an open learning related to creative problem solving abilities and the generated variance included making more friends, learning about classmates' habits and diverse points of view and knowing how to apply one's knowledge. We, therefore, should provide more open learning and focus on providing chances for learners to make new and various friends. Open learning allowed experienced persons to join the class, they learned about others' habits which helped them obtain various points of view to solve complex problems, study the problem and determine solutions based on shared experiences.

On behalf of the instructor, instructors should provide a chance for learners to ask questions and share their ideas by designing group discussions which relate to the ability to solve problem creatively and generate variances. This means providing a chance for learners to record different things and report progress of idea sharing every time. In addition, different ideas from group members should be collected, this analysis obtained from student's opinion with the benefits of working with others included listening to others' ideas (Mean=3.41), the access to source information for work (Mean=3.21), and the ability to include colleagues' ideas (Mean =3.09) and the benefits of group discussion behavior included listening to group members' ideas (Mean=3.32); collecting ideas from group members (Mean $=3.13$ ); and the motivation, support, and encouragement received from group members (Mean=3.09). In case of choosing some ideas, it should be voting on to obtain the best collaboration. Open learning was another mechanism to move forward teaching by focusing on development of abilities to solve the problems of learners. Ideal learners are students who can work with others and provide encouragement, support and motivation to other group members. They should be helpful to their colleagues in order to complete the assigned tasks and take care to share ideas. This is a guideline for instructor to design one's own open learning environment that encourages the development of creative problem solving abilities.

Further, applied tools in open learning are important. The researcher studied and synthesized the related literature and classified those teaching media as: time integrated and non-time integrated media, cloud storage, or social networking. The data collected from the questionnaire is student's opinion with the usage level of teaching and learning media included time integrating tools, namely in the Discussion room (Mean=3.18), Live video (Mean=2.11), Teleconferencing (Mean=1.56), non-time integrating tools including email (Mean=3.21), group division (Mean =2.88), calendar 
use (Mean=2.88), cloud storage namely Google drive (Mean =3.21), Dropbox (Mean $=2.60)$, One drive (Mean =2.10), and social media including Facebook: (Mean =4.65), Line (Mean =4.46) and Instagram (Mean =3.31) and correlation between Usage of learning and teaching and Creative problem solving abilities $=.334^{* *}$ found that teaching media related to creative problem solving abilities included bulletin boards applied with leaner based group activities by collecting different ideas from different sources and presentations by classmates or group members.

The above research findings are a guideline for instructors to emphasize on open learning design to develop creative problem solving abilities of graduate students. It provides a chance to learn different points of view and exchange knowledge among students in the course and extra curriculum students. Open learning also promotes, supports, and prepares students for when they finish the course to work collaboratively and become life- long learners.

Suggestions for future research includes collecting data from extra curriculum students or the general public, along with instructors or professors in the university who are using open learning and influencing variables towards creative problem solving activities. In addition, future research should analyze components of creative problem solving abilities and open learning that will develop creative problem solving abilities for graduate students to meet the requirement to possess 21 st century skills.

\section{Acknowledgment}

We thank you Associate Professor Dr. Jaitip Na Songkhla, thesis advisor and supportive scholarship granted by "90 year scholarship, Chulalongkorn University" batch 26. Expert research contributor: J. Ana Donaldson (Ed.D) University of Northern Iowa, USA - Retired

\section{$7 \quad$ References}

[1] RESouRCE, A., \& GuidE, P. (2008). 21st Century Skills, Education \& Competitiveness.

[2] Isaksen, S. G., Dorval, K. B., \& Treffinger, D. J. (2010). Creative approaches to problem solving: A framework for innovation and change: Sage Publications.

[3] Nouri, J., Åkerfeldt, A., Fors, U., \& Stockholm, S. S. (2017). Assessing Collaborative Problem Solving Skills in Technology-Enhanced Learning Environments-The PISA Framework and Modes of Communication. International Journal of Emerging Technologies in Learning, 12(4). https://doi.org/10.3991/ijet.v12i04.6737

[4] Zhou, C. (2016). Handbook of Research on Creative Problem-Solving Skill Development in Higher Education: IGI global.

[5] Hargrove, R. A., \& Nietfeld, J. L. (2015). The impact of metacognitive instruction on creative problem solving. The Journal of Experimental Education, 83(3), 291-318. https://doi.org/10.1080/00220973.2013.876604

[6] Higgins, J. M. (2006). 101 Creative Problem Solving Techniques: New Management Pub Co.

[7] Tahiri, J. S., Bennani, S., \& Idrissi, M. K. (2017). diffMOOC: Differentiated Learning Paths Through the Use of Differentiated Instruction within MOOC. 
[8] McAuley, A., Stewart, B., Siemens, G., \& Cormier, D. (2010). The MOOC model for digital practice.

[9] Na-songkhla, J. (2011). No boundaries of Learning: An OpenLearn system at Chulalongkorn University. Paper presented at the Global Learn 2011, Melbourne, Australia. https://www.learntechlib.org/p/37380

[10] Simpson, O. (2013). Supporting students in online open and distance learning: Routledge. https://doi.org/10.4324/9780203062395

[11] Moore, M. G. (2013). Handbook of distance education: Routledge. https://doi.org/10.4324/ 9780203803738

[12] Rovinelli, R. J., \& Hambleton, R. K. (1976). On the use of content specialists in the assessment of criterion-referenced test item validity.

[13] Cronbach, L. J.(1990). Essentials of psychological testing. New York, happer and Row publishers.

[14] Green, S. B., \& Salkind, N. J. (2010). Using SPSS for Windows and Macintosh: Analyzing and understanding data: Prentice Hall Press.

[15] Hinkle, D. E., Wiersma, W., \& Jurs, S. G. (2003). Applied statistics for the behavioral sciences.

\section{Authors}

Narin Nonthamand, Ph. D. Candidate, Doctor of Philosophy, Department of Educational Technology and Communications, Faculty of Education Science, Chulalongkorn University, Bangkok, Thailand 10330 (Narin.N@student.chula.ac.th).

Associate Professor Dr. Jaitip Na-Songkhla, Lecturer at the Department of Educational Technology and Communication, Faculty of Education Science, Chulalongkorn University, Bangkok, Thailand 10330 (Jaitip.N@chula.ac.th).

Article submitted 14 October 2017. Resubmitted 07 December 2017. Final acceptance 05 February 2018. Final version published as submitted by the authors. 